Sains Malaysiana 49(7)(2020): 1639-1649

http://dx.doi.org/10.17576/jsm-2020-4907-15

\title{
Combination of Honey Supplementation and Countermovement Jumping Exercise Influence Bone Turnover Markers in Young Males
}

(Gabungan Pengambilan Madu dan Senaman Lompatan Berpantul Mempengaruhi Penanda Metabolisme Tulang dalam Kalangan Lelaki Muda)

\author{
Muhammad Imran Mohd Zuhri, Mohamed Mirza Dawlath Mohamed, Ooi Foong Kiew \& Nur \\ SYAMSINA AHMAD*
}

\begin{abstract}
This study investigated the combined effects of Tualang Honey (TH) and countermovement jumping (CJ) exercise for 6 weeks on bone speed of sound (SOS), bone turnover markers, and maximum jumping height in young males. Forty participants aged between 18-24 years old were randomly assigned into four groups, i.e. control (C), supplementation of TH $(H)$, CJ exercise (J), and combined TH supplementation, and CJ exercise (JH) groups. Participants in the $J$ and JH groups were required to jump for 2 sessions/day, 3 alternated days/week for 6 weeks. Participants in the $H$ and JH groups consumed $20 \mathrm{~g} /$ day of TH for 6 weeks. Bone SOS of the participants' leg was measured at pre-and post-tests, and it was found that there were no significant differences in participants' bone SOS in all groups. Blood samples were analysed for determining the concentration of serum alkaline phosphatase (ALP) and serum C-terminal telopeptide of type-1 collagen (1CTP). The JH group showed a 56.3\% reduction in serum 1 CTP and was significantly lower $(p<0.01)$ than the C group. A 7.66\% reduction of ALP was observed in the JH group. Maximum jumping height was significantly greater $(p<0.05)$ in post-tests compared to pre-tests in the H and JH groups. In addition, there was a significantly greater maximum jumping height $(p<0.05)$ in the JH group compared to the C group in post-tests. In conclusion, the combination of TH with CJ exercise could significantly increase maximum jumping height compared to the control and this combination influence bone turnover markers in young males.
\end{abstract}

Keywords: Bone formation; bone health status; bone resorption; honey; jumping

\section{ABSTRAK}

Kajian ini mengkaji kesan gabungan Madu Tualang (TH) dan senaman lompatan berpantul (CJ) selama 6 minggu ke atas kelajuan bunyi tulang (SOS), penanda metabolisme tulang dan ketinggian lompatan maksimum dalam kalangan lelaki muda. Empat puluh orang peserta berumur antara 18-24 tahun telah dibahagikan secara rawak ke dalam empat kumpulan: kumpulan kawalan $(C)$, pengambilan TH $(H)$, senaman $C J(J)$ dan gabungan pengambilan TH dan senaman CJ (JH). Peserta dalam kumpulan J dan JH perlu melompat sebanyak $2 \mathrm{sesi} / \mathrm{sehari,} 3 \mathrm{kali} / \mathrm{seminggu}$ selama 6 minggu. Peserta dalam kumpulan H dan JH telah mengambil TH $20 \mathrm{~g} /$ sehari selama $6 \mathrm{minggu}$. SOS tulang kaki setiap peserta diukur semasa pra-dan pasca-ujian, dan tiada perbezaan signifikan terhadap SOS tulang peserta dalam setiap kumpulan. Sampel darah dianalisa untuk menentukan kepekatan serum alkali fosfatase (ALP) dan serum telopeptida C-terminal jenis-1 kolagen (1CTP). Kumpulan JH menunjukkan peratusan penurunan sebanyak $56.3 \%$ untuk serum 1CTP dan kadar 1CTP lebih rendah secara signifikan $(p<0.01)$ dalam kumpulan JH berbanding kumpulan C semasa pasca-ujian. Penurunan sebanyak 7.66\% serum ALP dalam kumpulan JH. Ketinggian lompatan maksimum yang lebih signifikan $(p<0.05)$ semasa pasca-ujian dibandingkan dengan pra-ujian dalam kumpulan $H$ dan JH. Tambahan lagi, penambahan yang signifikan terhadap ketinggian lompatan maksimum $(p<0.05)$ dalam JH dibandingkan dengan kumpulan C. Kesimpulannya, gabungan TH dan senaman CJ secara signifikan meningkatkan ketinggian lompatan maksimum berbanding dengan kumpulan $C$ dan mempengaruhi penanda metabolisme tulang dalam kalangan lelaki muda.

Kata kunci: Lompatan; madu; pembentukan tulang; penyerapan tulang; status kesihatan tulang

\section{INTRODUCTION}

Throughout human life, bone continually remodelled, which begins with the removal of older bone cells (bone resorption) and followed with the replacement of new cells (bone formation). The activities of bone resorption and bone formation depend on osteoclasts 
and osteoblasts regulation. Bone metabolism changes can be detected indirectly via blood markers of bone metabolism (Christenson 1997; Ooi \& Shahrir 2018). Osteocalcin which is produced by osteoblast during matrix mineralisation of bone formation and several other resorption biomarkers enable the evaluation of acute changes in bone metabolism or turnover in response to biological and biomechanical variables (Remes et al. 2004). The imbalance between osteoblast and osteoclast activity could lead to bone loss. This imbalance can result in bone diseases, including osteoporosis (Florencio-Silva et al. 2015).

Quantitative ultrasound (QUS) is a mechanical wave that can be influenced by bone structure ( $\mathrm{Njeh}$ et al. 2001). Two parameters commonly generated by QUS are the SOS and the broadband ultrasound attenuation (BUA). The speed of sound refers to the division of transmission time of the sound waves by the length of the body part studied. The unit used in the measurement of SOS is meter per second (m/s) (Chin et al. 2013).

The prevalence of low bone mineral density (BMD) was high among sedentary compared to physically active men (Chin \& Ima-Nirwana 2012) because of their active lifestyle. Bone density can be enhanced through performing high impact exercises. High impact exercises could produce force and bone load, which will strengthen the bone in physically active normal individuals (MacKelvie et al. 2002) and osteoporotic patients (Benedetti et al. 2018). Jumping exercise is considered as a type of high impact exercise that produces great osteogenic effects (Kato et al. 2006; Turner \& Robling 2003). This could stimulate bone formation and reduce bone resorption activity (Matthews et al. 2006) such as in tibia bone strain (Wang et al. 2019). Jumping exercise is needed to increase high stimulation on the bone (Hong \& Kim 2018; Ooi et al. 2014; Tavafzadeh et al. 2011) and maintain exercise-induced bone gains (Tavafzadeh et al. 2015). A training program following the gradual progressive approach in the jumping exercise was recommended to adapt to physiological changes on the bone (Erickson \& Vukovich 2010).

Nutrition also plays an important role in enhancing and maintaining bone health. Honey contains mainly carbohydrates, vitamins, and some minerals such as calcium, phosphorus, and magnesium, which are believed to be beneficial to bone health (Ooi et al. 2011). Honey consumption resulted in prolonged survival of osteoblasts and reduction of osteoclastogenic activity, and consequently, reduction in bone loss (Mohd Effendy et al. 2012). Honey can enhance collagen synthesis and stimulate alkaline phosphatase (ALP), a marker for osteoblast formation (Morton et al. 2001).

Among the different types of honey (e.g., Tualang, Gelam, Indian forest, Pineapple honey), Tualang Honey
(TH) has the highest antioxidant such as phenolic content which allows the reduction of oxidative stress in bone (Mohd Effendy et al. 2012). Tualang Honey (Koompassia excelsa) is a type of multi-floral honey produced by the rock bee species (Apis dorsata) that build hive high up in the branches of the Tualang Trees (Azman et al. 2015). It can be found in Indonesia, Malaysia, the Philippines, and Thailand. Tualang Honey has the highest phenolic compound and flavonoid contents with the highest ferric reducing power values as well as the greatest colour intensity, indicating that it has the highest antioxidant potential (Moniruzzaman et al. 2013).

A previous study reported an increase in BMD in postmenopausal females feeding with TH alone for 16 weeks (Shafin et al. 2014). Tualang Honey was also found to have beneficial effects on bone metabolism after TH consumption with or without jumping exercise for 8 weeks in rats (Tavafzadeh et al. 2015). A study by Rahim et al. (2016) found that the combination of $20 \mathrm{~g}$ of $\mathrm{TH}$ with aerobic exercise has the potential to reduce the increment in bone resorption resulting from exercise in adult women after 8 weeks. A study from Ooi et al. (2011) also found that the ingestion of TH dosage (20 g/ day) in 6 weeks was sufficient to increase bone formation markers (ALP) and reduce bone resorption markers [C-terminal telopeptide type - 1 collagen (1CTP)] in young females. As the $20 \mathrm{~g}$ of TH were sufficient to affect bone turnover, therefore the same dosage was used in this present study to see the combined effects of jumping exercise and $\mathrm{TH}$ was consumed for 6 weeks on the bone SOS, bone turnover markers, and maximum jumping height in young males.

\section{MATERIALS AND METHODS}

\section{STUDY DESIGN}

This study was a randomised controlled trial study (block randomisation was used by using a computerbased random number) and employed an opportunistic sampling method. The participants were randomly assigned into four groups: Control (C), Honey (H), Jumping $(\mathrm{J})$ and Jumping Honey $(\mathrm{JH})$ group after matching the age and body weight of the participants. The participants in the $\mathrm{C}$ and $\mathrm{H}$ groups were not involved with jumping exercise, while participants in the $\mathrm{J}$ and JH groups were involved with the jumping exercise which was performed twice a day, 3 times per week for 6 weeks. Meanwhile, the participants in the $\mathrm{H}$ and $\mathrm{JH}$ groups consumed $20 \mathrm{~g}$ of TH every morning at 8:00 a.m. At preand post-tests, bone SOS, was measured at tibia middle shaft of the participants' dominant leg. Blood samples were analysed for bone turnover markers (ALP and ICTP) at pre- and post-tests. Besides, a questionnaire of Bone 
Physical Activity Questionnaire (BPAQ) was used to reflect participant's physical activity levels which affect bone health status.

\section{SAMPLE SIZE CALCULATION}

The sample size was estimated using G-Power version 3.1.9 and data from a previous study conducted by Ooi et al. (2011). The power of the study was set at $80 \%$, with a $95 \%$ confidence interval, and an effect size of 1.22 . The calculated sample size was 8 per group. However, after taking into account a $20 \%$ drop out rate the participants per group was 10 , and the total participants in the study were 40 participants.

\section{PARTICIPANTS AND RECRUITMENT}

Forty healthy young males participated in this study. Participants were given the study information sheet and received an explanation about the study procedures such as the experimental protocol and possible risks before being given the consent form for signing. Participants' participation in this research was voluntary. Participants had the right to withdraw from this research anytime. The inclusion criteria were: healthy male, aged between 18-24 years old, physically non-active who exercised less than 2 times per week. While the exclusion criteria were: involved in any competition or training, had health problems such as asthma, previous lower limb fracture (of the last 2 years), diabetes, and high blood pressure, had injuries in the last 6 months, having the habit of taking honey regularly, on medication (usage of antibiotics for the past 2 weeks) or consumed any nutritional supplement.

The participants of this study consisted of Health Campus, Universiti Sains Malaysia (USM) Kubang Kerian, Kelantan students and residents living nearby Kubang Kerian. Recruitments of the participants were based on face to face approach, emails, and advertisement through flyers and posters. Posters were posted on the notice boards at the dormitories, and cafeteria areas, and flyers were distributed at the university passage areas. This study was approved by Universiti Sains Malaysia (USM) Research Ethics Committee (USM/ JEPeM/18020156), and all the participants had provided their written consent.

\section{HONEY SUPPLEMENTATION}

In this study, participants consumed TH for 6 weeks. Federal Agricultural Marketing Authority (FAMA) Malaysia provided the TH from a single batch of honey. The honey was extracted from the same source and used without additional processing and treatment.
Participants were required to consume $20 \mathrm{~g}$ of honey daily. The honey was consumed in liquid form by measuring using a syringe to get the exact amount. Participants were asked to refrain from consuming any products or supplement containing especially vitamin (A, $\mathrm{C}, \mathrm{D}$, and E), fatty acid or amino acid, and to refrain from participating in any vigorous physical activities during the study period. Participants of the $\mathrm{H}$ and $\mathrm{JH}$ groups were required to tick the checklist of honey consumption every day as per reminder by the researcher through WhatsApp massages and calls. Then, participants were asked to submit the checklist every 2 weeks to the researcher for ensuring the compliance of the participants. At the end of the intervention, participants returned the residue honey volume at the Sports Science Laboratory.

\section{COUNTERMOVEMENT JUMPING EXERCISE}

During the 6 weeks' intervention, participants in the $\mathrm{J}$ and $\mathrm{JH}$ groups performed jumping exercises based on their maximum jumping height calculated by force platform and Quatro Jump software at pre-tests. Before the actual jumping exercise, the researcher briefed the participants about the training schedules for the jumping activities (3 alternated days per week for 6 weeks). In the first week of jump training, participants were required to run through a familiarisation session under the researcher's supervision. Participants performed two-legged maximum vertical jumps using arm swing in countermovement style on 3 alternated days/week (Kato et al. 2006). The same jumping style was performed for another 5 weeks on a relatively hard floor with proper sports shoes. The interval of each jump was between 8-12 seconds, so the training session took less than 2 min. Five min before starting the training program, participants performed standardised warmup activities. The warm-up session included dynamic stretching based on Vetter (2007) protocol.

The participants were required to jump for 2 sessions per day i.e. 1st session: 9:00 a.m. to 11:00 a.m. and 2nd session: 3:00 p.m. to 5:00 p.m. (on 3 alternate days per week). The training protocol consisting of a 6 weeks intervention period following a progressive overload model (Table 1) (Erickson \& Vukovich 2010) provided to participants in the $\mathrm{J}$ and $\mathrm{JH}$ groups. The number of repetition was increased week by week. The load was also increased progressively as per Table 1 for body adaptation to meet higher physiological demands. The rest interval between sets was $1 \mathrm{~min}$. Throughout training intervention, jump training was supervised by the researcher for the participants to perform with the right technique and to avoid the occurrence of any accidents or injuries. 
TABLE 1. Training program for participants in jumping $(\mathrm{J})$ and combined jumping and honey $(\mathrm{JH})$ groups

\begin{tabular}{lccc}
\hline Week $(\mathrm{W})$ & Session 1 & Rest & Session 2 \\
\hline W 1 & 2 set of 5 jumps & $6 \mathrm{~h}$ & 2 set of 5 jumps \\
W 2 & 2 set of 7 jumps & $6 \mathrm{~h}$ & 2 set of 7 jumps \\
W 3 & 2 set of 10 jumps & $6 \mathrm{~h}$ & 2 set of 10 jumps \\
W 4 & 2 set of 15 jumps & $6 \mathrm{~h}$ & 2 set of 15 jumps \\
W 5 & 3 set of 8 jumps & $6 \mathrm{~h}$ & 3 set of 8 jumps \\
\hline
\end{tabular}

Adapted from Erickson and Vukovich (2010)

\section{ANTHROPOMETRIC AND BODY COMPOSITION MEASUREMENT}

Baseline testing for all groups included anthropometric and body composition measurements. The participants' body weight $(\mathrm{kg})$, height $(\mathrm{cm})$, body fat $(\%)$, and free fat mass (FFM) were measured using a bioimpedance analysis machine (TBF-410 $(50 \mathrm{kHz}, 500 \mu \mathrm{A})$, Tanita, Japan) during this session. During measurement, impedance is measured during standing position. The participants' age, gender, and height were entered on to the machine, and a standard $2 \mathrm{~kg}$ was entered as an adjustment for clothing weight in all participants. Inaccuracy in this estimation influences TANITA estimates the body composition. Participants were then asked to stand barefoot on the metal foot-plates of the machine for $1 \mathrm{~min}$. BMI value was derived from the following equation:

$$
\text { BMI = Body weight }(\mathrm{kg}) / \operatorname{Height}^{2}(\mathrm{~m})
$$

\section{VERTICAL JUMP HEIGHT DETERMINATION}

The participants' maximum vertical jump height was measured at pre- and post-tests by using a force platform with Quatro Jump software (Aragón 2000).

\section{BONE SPEED OF SOUND (SOS)}

In this study, quantitative ultrasound measurement of the bone SOS which can reflect bone density was measured by using a bone sonometer (Sunlight Mini OmniTM, Petah Tikva, Israel) at the participant's middle shaft tibia of the dominant leg. During the assessment, the participants were seated on a chair. They were required to straighten their dominant leg which was supported by a stool. The region of measurement for the tibia of the leg was defined as the mid-point between the plantar surface of the heel and the proximal edge of the knee. Then, ultrasound gel was applied on the skin surface along with the measurement site. The assessor rotated the transducer within the probe slowly around the measurement site without lifting it from the skin. The measurements of both sides were repeated for three times or more until the bone SOS value was obtained. Based on a previous study carried out by Nguyen et al. (2004), the intrasubject coefficient of variation in bone SOS measurement in a random sample of 30 subjects was between 0.4 and $1 \%$. High SOS reading reflects high bone SOS of an individual.

\section{BONE PHYSICAL ACTIVITY QUESTIONNAIRE (BPAQ) SCORE}

At the pre-tests, participants were required to answer bonespecific physical activity questionnaire (BPAQ; current BPAQ and past BPAQ). The total scores of current and past BPAQ were used to predict the participants' level of bone health status. This questionnaire contains 2 parts. In the first part, the questions are regarding sports activities that participants involved in childhood. In the second part of the questionnaire are regarding questions of any sport activities that participants involved for the past 12 months. Then, based on the results (different ground reaction force for different sports) answered by the participants, the researcher will calculate their BPAQ score based on the equation provided. For scoring if participant scores less than 40, it is considered as low value as mentioned in Week and Becks (2008) study which showed the participants were exposed to low mechanical bone loading during physical activities prior to the study period. For validation, the current activity component of BPAQ was a significant predictor of variance in femoral neck BMD, lumbar spine BMD, and whole body BMD (R2=0.36 $0.68, \mathrm{p}<0.01$ ) for men, while the past activity component of BPAQ predicted calcaneal broad-band ultrasound attenuation $(\mathrm{R} 2=0.48, \mathrm{p}=0.001)$.

\section{DAILY FOOD RECORD}

Participants were required to record the details of the food and beverages consumed across the intervention period. 
Their dietary intakes were reviewed by the researchers to clarify any issues on the records. This is important to ensure the participants avoid any kind of honey or supplement throughout the intervention period that may influence the bone remodelling markers of the subjects.

\section{BLOOD COLLECTION AND ANALYSIS}

At pre- and post-tests of the study, the laboratory technologist withdrew $3 \mathrm{~mL}$ of blood from participants' median cubital vein following $10 \mathrm{~h}$ overnight fasting (only plain water was allowed to drink during fasting) and kept in $6 \mathrm{~mL}$ plain tube. The blood samples in the plain tube were allowed to clot completely for at least $2 \mathrm{~h}$ and subsequently were centrifuged at 3000 revolutions per min for 15 min at $4{ }^{\circ} \mathrm{C}$ (Rotina 46 RS Hettich Zentrifugen German). The serum was divided into equal portions and stored in labelled Eppendorf tubes at $-40{ }^{\circ} \mathrm{C}$ for subsequent analysis of ALP and 1CTP. Serum ALP analysis was performed in an accredited pathology laboratory (BP Clinical Laboratory, Malaysia). Serum 1CTP concentration was determined using commercial kit human 1CTP ELISA kit (Wuhan EIAab Science Co, China) and measured on VersaMax ELISA microplate reader (Molecular Devise, USA).

\section{STATISTICAL ANALYSIS}

Statistical Package for Social Sciences Version 22.0 was used for the statistical analyses. The distribution of data for normality was assessed using ShapiroWilk test. Descriptive analysis was performed on the anthropometric characteristic of the participants. Twoway mixed ANOVA was performed to analyse data of blood parameters, jumping height, and bone sos for determining the significant differences between four groups and within the group itself. Significant differences demonstrated in two-way mixed ANOVA was followed by post-hoc Bonferroni's test. All data were reported as means \pm standard deviations.

\section{RESULTS}

PARTICIPANTS ANTHROPOMETRY CHARACTERISTICS, BONE PHYSICAL ACTIVITY QUESTIONNAIRE (BPAQ) SCORE, AND BONE SPEED OF SOUND (SOS)

A total of 40 participants with mean age: $22.2 \pm 1.3$ years, mean body weight: $62.0 \pm 9.8 \mathrm{~kg}$, mean body height: $168.7 \pm 5.9 \mathrm{~cm}$, and mean body mass index (BMI): $21.7 \pm$ $2.6 \mathrm{~kg} / \mathrm{m}$ completed the study. Table 2 tabulates baseline mean body weight, height, body mass index (BMI), percentage of body fat, FFM, BPAQ scores, bone SOS for the $\mathrm{C}, \mathrm{H}, \mathrm{J}$, and $\mathrm{JH}$ groups. There were no significant differences in all these measured parameters among the groups at pre-test.
PARTICIPANTS BODY WEIGHT AND FAT PERCENTAGE AT PRE- AND POST-TESTS

Means of body weight and percentage of body fat at pre- and post-tests of all groups are presented in Table 3. There was no significant main effect of time $\left(\mathrm{F}_{1,36}=2.356\right.$, $\mathrm{p}=0.134)$ and group $\left(\mathrm{F}_{3,36}=0.111, \mathrm{p}=0.953\right)$ for body weight. There was also no interaction between time and group $\left(\mathrm{F}_{3,36}=0.435, \mathrm{p}=0.729\right)$. Regarding fat percentage, there was no significant main effect of time $\left(\mathrm{F}_{1,36}=2.034\right.$, $\mathrm{p}=0.162)$ and group $\left(\mathrm{F}_{3,36}=0.147, \mathrm{p}=0.931\right)$. Similarly, there was also no interaction between time and group $\left(\mathrm{F}_{3,36}=\right.$ $1.303, \mathrm{p}=0.288$ ) for percentage body fat.

\section{MAXIMUM JUMPING HEIGHT OF COUNTERMOVEMENT JUMP}

Figure 1 shows the mean of maximum jumping height for all groups at pre- and post-tests and the percentage of change across time. There was a significant main effect of time $\left(\mathrm{F}_{1,36}=40.744, \mathrm{p}<0.01\right)$. However, there was no significant main effect of group $\left(\mathrm{F}_{3,36}=2.834, \mathrm{p}=0.052\right)$. Additionally, there was significant interaction between time and group $\left(\mathrm{F}_{3,36}=12.604, \mathrm{p}<0.01\right)$. Following up on this interaction, it was indicated that there was a significant difference $(\mathrm{p}<0.01)$ between pre- and post-tests in the $\mathrm{H}$ and $\mathrm{JH}$ groups with $+11.2 \%$ and $+20.5 \%$ increment, respectively. In addition, there was a significant greater jumping height $(\mathrm{p}=0.004)$ in the $\mathrm{JH}$ group compared to the $\mathrm{C}$ group at post-tests.

\section{BONE SPEED OF SOUND (SOS) OF THE TIBIA OF THE DOMINANT LEG}

Results of bone SOS at pre- and post-tests can be seen in Table 2. There was no significant difference after 6 weeks of intervention $\left(\mathrm{F}_{1,36}=3.636, \mathrm{p}=0.065\right)$ and no significant difference between group $\left(\mathrm{F}_{3,36}=0.354, \mathrm{p}=0.787\right)$ in the mean bone SOS. There was also no significant interaction between time and group $\left(\mathrm{F}_{3,36}=0.612, \mathrm{p}=0.611\right)$.

\section{BONE FORMATION MARKER: ALKALINE PHOSPHATASE} (ALP)

Table 2 illustrates the results of serum ALP. There was no significant main effect of time $\left(\mathrm{F}_{1,36}=0.242, \mathrm{p}=0.626\right)$ and group $\left(\mathrm{F}_{3,36}=0.107, \mathrm{p}=0.955\right)$. However, there was a significant interaction between time and group $\left(F_{3,36}=3.034, p=0.042\right)$. It was indicated that there was a statistically significant decrease $(p=0.024)$ in ALP concentration in the JH group. Although the decrease was significant statistically, the reduction was only $-7.66 \%$ after 6 weeks of intervention.

\section{BONE RESORPTION MARKER: SERUM C-TERMINAL TELOPEPTIDE OF TYPE-1 COLLAGEN (1CTP)}

Figure 2 shows the mean serum 1CTP for all groups at preand post-tests and the percentage of change across time. 
There was a significant main effect of time $\left(\mathrm{F}_{1,36}=19.402\right.$, $\mathrm{p}<0.01)$. However, there was no significant main effect of group $\left(\mathrm{F}_{3,36}=0.381, \mathrm{p}=0.767\right)$. Additionally, there was a significant interaction between time and group $\left(\mathrm{F}_{3,36}=\right.$ $3.233, \mathrm{p}=0.034)$. There were no significant differences in serum 1CTP between pre- and post-tests in the $\mathrm{C}, \mathrm{H}$,
$\mathrm{J}$, and $\mathrm{JH}$ groups. Nevertheless, 1CTP was significantly lower $(\mathrm{p}<0.01)$ statistically in the JH group than the $\mathrm{C}$ group at post-tests. The JH group also showed the highest percentage change among the groups, by reducing bone resorption markers concentration at post-tests with $56.3 \%$.

TABLE 2. Participant's baseline anthropometry characteristic, body composition, bone physical activity questionnaire (BPAQ) scores, and bone speed of sound (SOS)

\begin{tabular}{|c|c|c|c|c|}
\hline Variables & Control (C) & Honey $(\mathrm{H})$ & Jumping (J) & $\begin{array}{l}\text { Combined } \\
\text { Jumping and } \\
\text { Honey }(\mathrm{JH})\end{array}$ \\
\hline Age (years) & $22.9 \pm 1.4$ & $21.8 \pm 1.8$ & $22.2 \pm 1.0$ & $22.0 \pm 0.5$ \\
\hline Body weight (kg) & $61.6 \pm 11.2$ & $60.6 \pm 12.6$ & $62.9 \pm 7.5$ & $63.0 \pm 8.3$ \\
\hline Body height (cm) & $168.7 \pm 6.8$ & $167.8 \pm 8.2$ & $169.7 \pm 4.2$ & $168.7 \pm 4.5$ \\
\hline BMI (kg & $21.6 \pm 2.8$ & $21.5 \pm 3.4$ & $21.8 \pm 2.2$ & $22.1 \pm 2.5$ \\
\hline Body fat (\%) & $19.8 \pm 7.0$ & $19.7 \pm 6.1$ & $18.6 \pm 5.1$ & $18.5 \pm 4.8$ \\
\hline Free fat mass $(\mathrm{kg})$ & $48.6 \pm 6.8$ & $48.2 \pm 7.6$ & $51.0 \pm 4.5$ & $51.0 \pm 4.2$ \\
\hline Current BPAQ & $17.7 \pm 14.8$ & $16.2 \pm 9.6$ & $20.1 \pm 21.0$ & $11.5 \pm 9.1$ \\
\hline Past BPAQ & $13.4 \pm 9.2$ & $13.3 \pm 6.0$ & $11.5 \pm 11.2$ & $9.0 \pm 6.5$ \\
\hline Bone SOS $(\mathrm{m} / \mathrm{s})$ & $3941.3 \pm 71.8$ & $3880 \pm 305.8$ & $3844 \pm 293.3$ & $3925.7 \pm 98.0$ \\
\hline
\end{tabular}

TABLE 3. Mean body weight, body fat percentage, bone SOS and serum ALP concentration (U/L) at pre- and post-tests across groups

\begin{tabular}{|c|c|c|c|c|c|c|c|c|}
\hline \multirow[b]{2}{*}{$\begin{array}{l}\text { Variables } \\
\text { Time }\end{array}$} & \multicolumn{2}{|c|}{ Control (C) } & \multicolumn{2}{|c|}{ Honey $(\mathrm{H})$} & \multicolumn{2}{|c|}{ Jumping (J) } & \multicolumn{2}{|c|}{$\begin{array}{c}\text { Combined Jumping and } \\
\text { Honey }(\mathrm{JH})\end{array}$} \\
\hline & Pre test & Post test & Pre test & Post test & Pre test & Post test & Pre test & Post test \\
\hline $\begin{array}{l}\text { Body weight } \\
(\mathrm{kg})\end{array}$ & $61.5 \pm 11.2$ & $61.8 \pm 11.0$ & $60.6 \pm 12.2$ & $61.4 \pm 11.3$ & $62.9 \pm 8.3$ & $63.0 \pm 8.2$ & $63.0 \pm 8.3$ & $63.4 \pm 8.3$ \\
\hline $\begin{array}{l}\text { Body fat } \\
\text { percentage }(\%)\end{array}$ & $19.8 \pm 7.0$ & $19.7 \pm 6.2$ & $19.7 \pm 6.1$ & $20.4 \pm 4.5$ & $18.6 \pm 5.1$ & $18.4 \pm 5.3$ & $18.5 \pm 4.8$ & $20.1 \pm 5.2$ \\
\hline Bone SOS $(\mathrm{m} / \mathrm{s})$ & $\begin{array}{c}3941.3 \pm \\
71.8\end{array}$ & $\begin{array}{c}3938.2 \pm \\
113.6\end{array}$ & $\begin{array}{c}3880 \pm \\
305.8\end{array}$ & $\begin{array}{c}3987.8 \pm \\
106.8\end{array}$ & $\begin{array}{c}3844 \pm \\
293.3\end{array}$ & $\begin{array}{c}3936.3 \pm \\
96.8\end{array}$ & $\begin{array}{c}3925.7 \pm \\
98.0\end{array}$ & $\begin{array}{c}3972.0 \pm \\
80.9\end{array}$ \\
\hline $\begin{array}{l}\text { Serum ALP } \\
(\mathrm{U} / \mathrm{L})\end{array}$ & $70.5 \pm 19.4$ & $74.6 \pm 21.0$ & $74.8 \pm 11.7$ & $79.1 \pm 17.5$ & $74.0 \pm 14.7$ & $77.0 \pm 19.0$ & $79.5 \pm 26.5$ & $\begin{array}{c}71.1 \pm \\
17.1^{\mathrm{a}}\end{array}$ \\
\hline
\end{tabular}

Values are mean \pm standard deviation (SD), SOS, speed of sound, ALP, Alkaline phosphatase. ${ }^{a} \mathrm{p}<0.05$ significantly from pre test 


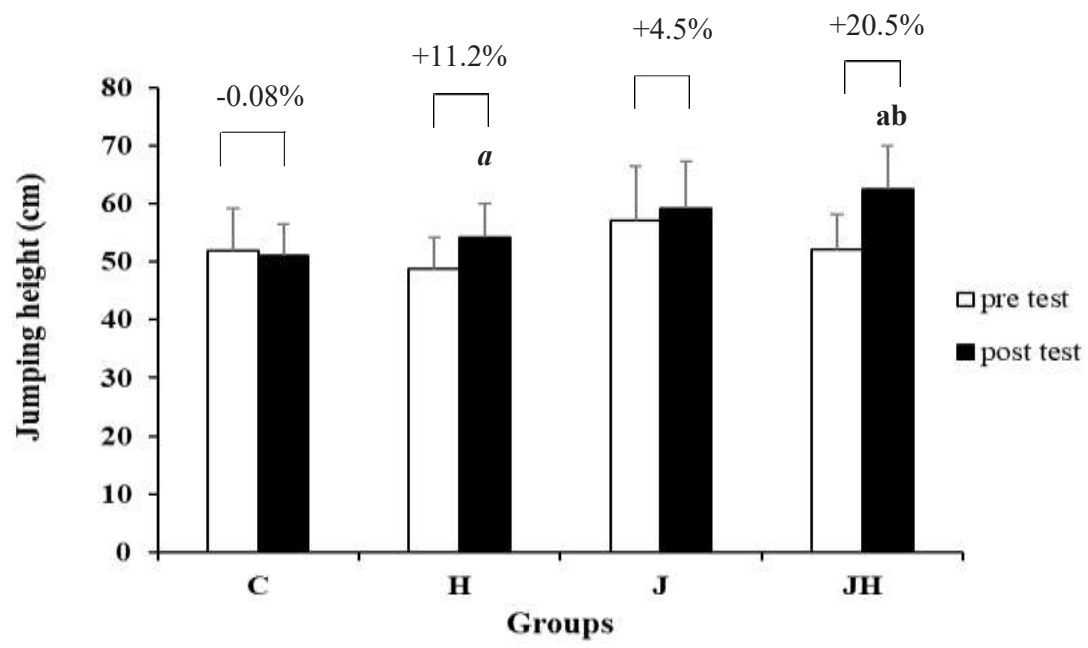

FIGURE 1. Maximum jumping height $(\mathrm{cm})$ at pre- and post-tests

${ }^{\mathrm{a}} \mathrm{p}<0.05$ significantly from pre-test, ${ }^{\mathrm{b}} \mathrm{p}<0.05$ significantly different from control group at post-test

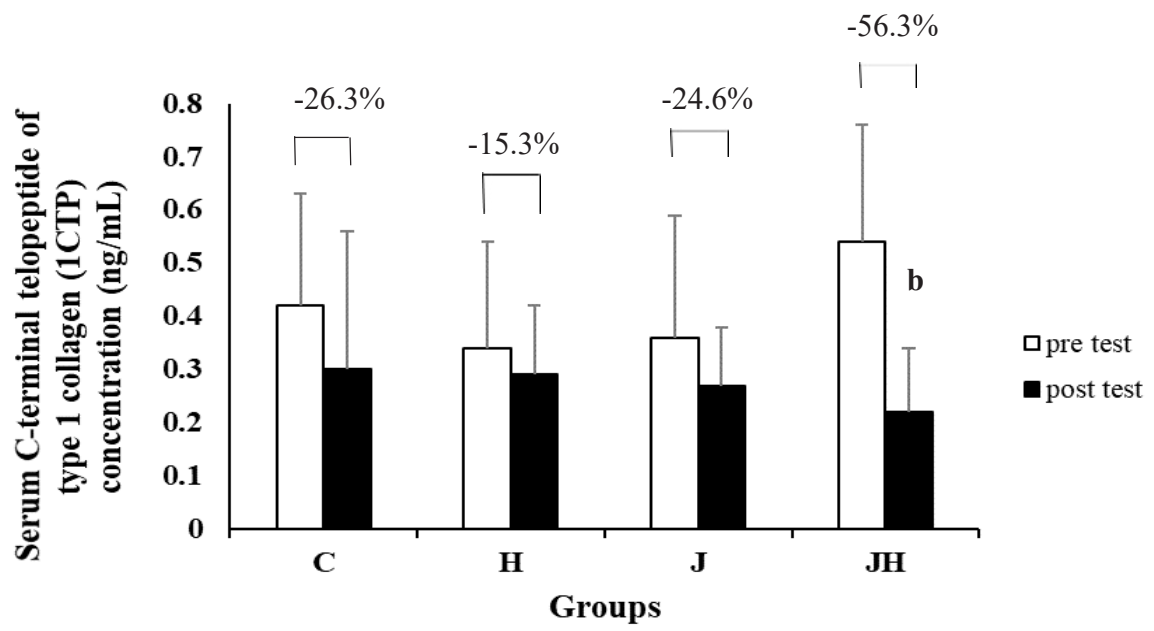

FIGURE 2. Serum C-terminal telopeptide of type 1 collagen (1CTP) concentration $(\mathrm{ng} / \mathrm{mL})$ at pre- and post- tests

${ }^{b} \mathrm{p}<0.05$ significantly different from control group at post-test

\section{DISCUSSION}

In the present study, it was found that there were no significant differences in age, body weight, height, BMI, and percentage of body fat among all four groups at the beginning of the study. However, total BPAQ scores of $31.1 \pm 24$ in C, $29.5 \pm 15.6$ in $\mathrm{H}, 31.6 \pm 32.2$ in $\mathrm{J}$, and $20.5 \pm 15.6$ in $\mathrm{JH}$ groups were categorised as lower value as mentioned in Weeks and Beck (2008) study which showed that the participants were exposed to low mechanical bone loading during physical activities prior to the study period.

After 6 weeks' intervention, the present study also found that there were no significant differences in body weight and fat percentage at pre- and post-tests in the $\mathrm{H}$ and $\mathrm{J}$ groups. Combined honey and jumping $(\mathrm{JH})$ also did not affect participants' body weight and fat percentage. 
Kromhout et al. (2001) observed that physical activities was negatively associated with BMI and body fat and suggested that regular exercise could decrease body weight and body fat significantly. It was speculated that the differences between the findings of the present and previous studies could be due to differences in gender and age of the participants, types of exercises, the intensity of exercise, and types of nutritional supplementations.

The main finding of the present study was that consumption of honey supplementation in the $\mathrm{H}$ and $\mathrm{JH}$ groups for 6 weeks significantly $(\mathrm{p}<0.05)$ increased jumping height compared to the $\mathrm{C}$ and $\mathrm{J}$ groups. Jumping height significantly increased by 11.2 and $20.5 \%$ in the $\mathrm{H}$ and the JH groups, respectively. In addition, the JH group elicited a more significant effect on jumping height than the $\mathrm{H}$ group. This was based on the observation that the JH group showed a statistically significantly higher value than the $\mathrm{C}$ group at the post-tests, and this difference was not observed between the $\mathrm{H}$ group and the $\mathrm{C}$ group.

Jumping exercise is a type of high impact weightbearing exercise that can produce large ground reaction force and strong muscular contraction force. It is believed that jumping exercise is considered more effective as compared to low impact or non-weight-bearing exercises to increase muscular and bone strength (Fuchs et al. 2001). According to Rahim et al. (2016), carbohydrate is the primary source of energy during exercise. It was speculated that there was an increase in the absorption of carbohydrates and vitamins contained in the honey into the muscles through the enhancement of blood flow elicited by physical activities. In the presence of carbohydrates, the working muscles of the participants were able to generate more energy and managed to carry out the exercises more efficiently, and consequently, muscular strength can be improved. Consistently, the present study also found that combined jumping exercise with honey could increase jumping height which may be caused by the greater muscular strength of the legs in young males.

Physical activities have reported could increase bone formation markers and decrease bone resorption markers in the animals as well as in humans (Fujimura et al. 1997). As the bone is a highly active organ metabolically, it is always in a continuous dynamic remodelling process that maintained in a tightly coupled balance between resorption of old bone and formation of new bone (Christenson 1997). In the present study, serum ALP was measured as a biomarker of bone formation, and 1CTP was measured as a biomarker of bone resorption.

Regarding the bone resorption marker, the $\mathrm{JH}$ group showed the highest percentage reduction of 1CTP concentration among the groups, i.e. 56.3\%. In addition, 1CTP was significantly lower in the JH group compared to the $\mathrm{C}$ group at the post-tests. The finding of this study implied that the $\mathrm{JH}$ group might have the potential of reducing bone resorption after 6 weeks of intervention in young males. In the animal study of Ooi et al. (2012) it was reported that serum 1CTP concentration decreased in the rats which were given workloads of 40 jumps per week and above for a total of 24 weeks. In another animal previous study carried out by Mosavat et al. (2014), it was evidenced that serum 1CTP levels were significantly lower in honey alone groups, 20 jumps per day group, 80 jumps per day group, and combined 20 and 80 jumps per day with honey group when compared to sedentary without honey supplementation control group. Reduction in bone resorption marker with 16 weeks of combined jumping exercise and honey supplementation was reported in another animal study by Tavafzadeh et al. (2015).

Nevertheless, in a human study done by Ooi et al. (2011), it was found that aerobic dance exercise consisted of $1 \mathrm{~h}$ per day, 3 times per week combined with $20 \mathrm{~g}$ of Gelam Honey for 7 days per week for a duration of 6 weeks, did not show any significant effect on serum (1CTP) in young females. The discrepancy between the present study and previous studies results could be due to variations in the types and duration of the physical training prescribed and kinds of recruited subjects, e.g., animals or humans studies. Honey contains vitamin K, and minerals such as calcium, phosphorus, iron, and magnesium, which are essential for increasing bone health. The high volume of blood could be delivered to the working muscles when the participants performed countermovement jumping exercise. The speculation of the reason of the reduction in bone resorption marker in the $\mathrm{JH}$ group of the present study is that there was an absorption of the nutrients which are beneficial for bone health contained in honey into the blood and subsequently transported into the muscle and bone, caused by the dynamic loading elicited by jumping exercise. Based on the previous study by Mohd Effendy et al. (2012), TH contained a high level of phenolic and flavonoid contents (included quercetin, keampferol, and ascorbic acid), an antioxidant which shown to inhibit NF-kB, AP-1 and RANKL by inducing osteoclast activities. Subsequently, these phytonutrients could inhibits bone resorption which then inhibit bone loss and increase bone density.

The present study's findings on the significant reduction of ALP in the JH group were not consistent with a previous human study involving young females by Ooi et al. (2011). In their study, combined aerobic dance exercise and honey supplement group (HEx) exhibited the highest percentage increment in serum ALP, a bone formation marker among the experimental groups. The authors mentioned that a HEx group might elicit more beneficial effects on increasing bone formation marker compared to the honey supplementation alone $(\mathrm{H})$ group or aerobic dance exercise (Ex) group generally. This previous study also showed that there was a statistically 
significantly higher value of serum ALP in the $H$ and HEx after the 6 weeks' experimental period compared to their pre-tests value, respectively. Nevertheless, the percentage increase of serum ALP was greater in the HEx group $(+31.79 \%)$ than the $H$ group $(+15.91 \%)$.

In another previous study by Ooi and Aziz (2017) on honey combined with circuit training, serum ALP significantly increased in young males. The circuit training consisted of 2 circuits with 10 different activities, e.g., hand elastic bend exercise, leg elastic bend elastic, free-weight dumbbell triceps extension, rope skipping, free-weight dumbbell concentration curl, sit-up, back extension, burpee, push-up and split squat. The circuit training was performed 3 times per week for 6 weeks. They found that 6 weeks of combined circuit training and daily honey consumption of $20 \mathrm{~g}$ of honey diluted in $300 \mathrm{~mL}$ of plain water elicited beneficial effects on increasing bone formation marker of blood ALP in young males. Their finding implies that a combination of honey and exercise elicited the greatest effects in increasing serum ALP, a bone formation marker among all groups. Findings on serum ALP in the present study were not consistent with Ooi and Aziz (2017) and Ooi et al. (2011). Further study is needed to clarify these inconsistent observations.

In the present study, we also measured bone SOS of the dominant leg of the participants. It was found that there were no statistically significant differences in bone SOS between the $\mathrm{C}, \mathrm{H}, \mathrm{J}$, and JH groups. This result implies that the $\mathrm{H}, \mathrm{J}$, and $\mathrm{JH}$ groups did not affect bone SOS, which represents the bone health status of the young males in the present study. This result also reflects that there were no changes in bone SOS after 6 weeks of the study period. It speculated that the study period was too short for eliciting changes in bone SOS in young males. Therefore, further study with a longer period is recommended to be conducted for gaining significant positive results.

The present study's findings were not consistent with the other two animal studies with combined jumping exercise and honey supplementation. In the previous animal study carried out by Mosavat et al. (2014), it was observed that bone wet and fat-free dry weights as indicators of bone mass with both organic and mineral phases were greater in high intensity jumping combined with honey supplementation group than all the other experimental groups. Another animal study by Tavafzadeh et al. (2015) also found that 16 weeks of jumping exercise combined with honey supplementation increased tibial proximal total bone density, proximal trabecular bone density, midshaft cortical bone density, tibial cortical area, midshaft cortical moment of inertia, maximum force, and energy as compared to sedentary control group. However, 16 weeks of jumping exercise alone merely showed improvement in tibial proximal trabecular bone density, cortical area, a midshaft cortical moment of inertia, and maximum force. These findings indicated that more beneficial bone effects could be observed when jumping exercise combined with honey supplementation compared with jumping exercise alone.

Dimitriou et al. (2011) mentioned that it may take some time to repair and develop new cells in the bone to be compact and strong. The present study's results on bone SOS were not consistent with a previous study by Zaid (2010), which reported that administration of TH $(0.2 \mathrm{~g} / \mathrm{kg} \mathrm{BW})$ to ovariectomised rats for 6 weeks significantly restores the tibia bones, compared to the rats that received calcium. The differences in the study findings observed in this previous animal studies compared to the present human study could be due to the timing of honey absorption mechanism in humans and animals may have different pathways, and needs different duration to give similar beneficial effects on bone. For instance, Mosavat et al. (2014) reported increased in indicator of bone mineral density with short duration i.e. 8 weeks of combined honey and jumping exercise in rats. However, an increase in bone SOS, could not be observed in the present human study with 6 weeks of intervention. In future studies should include DXA data for BMD and body composition analysis.

\section{CONCLUSION}

As a conclusion, combination of countermovement jump and honey supplementation has the potential to be proposed for formulating guidelines in planning exercise and nutritional promotion programs for increasing maximum jumping height and influencing bone turnover in young males.

\section{ACKNOWLEDGEMENTS}

This project was funded by the Universiti Sains Malaysia KPI incentive grant (1001/PPSK/ AUPS001). A special thanks goes to all participants for their cooperation and support for this study.

\section{REFERENCES}

Aragón, L.F. 2000. Evaluation of four vertical jump tests: Methodology, reliability, validity, and accuracy. Measurement in Physical Education and Exercise Science 4(4): 215-228.

Azman, K.F., Zakaria, R., Abd Aziz, C., Othman, Z. \& Al-Rahbi, B. 2015. Tualang honey improves memory performance and decreases depressive-like behavior in rats exposed to loud noise stress. Noise Health 17(75): 83-89.

Benedetti, M.G., Furlini, G., Zati, A. \& Letizia Mauro, G. 2018. The effectiveness of physical exercise on bone density in osteoporotic patients. BioMed Research International 2018: Article ID. 4840531.

Chin, K.Y. \& Ima-Nirwana, S. 2012. Sex steroids and bone health status in men. International Journal of Endocrinology 2012: Article ID. 208719. 
Chin, K.Y., Soelaiman, I.N., Mohamed, I.N., Mohamed, N., Shuid, A.N., Muhammad, N. \& Ngah, W.Z.W. 2013. Discrepancy between the quantitative ultrasound value of Malaysian men and the manufacturer's reference and the impact on classification of bone health status. Journal of Clinical Densitometry 16(2): 189-195.

Christenson, R.H. 1997. Biochemical markers of bone metabolism: An overview. Clinical Biochemistry 30(8): 573-593.

Dimitriou, R., Jones, E., McGonagle, D. \& Giannoudis, P.V. 2011. Bone regeneration: Current concepts and future directions. BMC Medicine 9(1): 66.

Erickson, C.R. \& Vukovich, M.D. 2010. Osteogenic index and changes in bone markers during a jump training program: A pilot study. Medicine and Science in Sports and Exercise 42(8): 1485-1492.

Florencio-Silva, R., Sasso, G.R.D.S., Sasso-Cerri, E., Simões, M.J. \& Cerri, P.S. 2015. Biology of bone tissue: Structure, function, and factors that influence bone cells. BioMed Research International 2015: Article ID. 421746.

Fuchs, R.K., Bauer, J.J. \& Snow, C.M. 2001. Jumping improves hip and lumbar spine bone mass in prepubescent children: A randomized controlled trial. Journal of Bone and Mineral Research 16(1): 148-156.

Fujimura, R., Ashizawa, N., Watanabe, M., Mukai, N., Amagai, H., Fukubayashi, T., Hayashi, K., Tokuyama, K. \& Suzuki, M. 1997. Effect of resistance exercise training on bone formation and resorption in young male subjects assessed by biomarkers of bone metabolism. Journal of Bone and Mineral Research 12(4): 656-662.

Hong, A.R. \& Kim, S.W. 2018. Effects of resistance exercise on bone health. Endocrinology and Metabolism 33(4): 435444.

Kato, T., Terashima, T., Yamashita, T., Hatanaka, Y., Honda, A. \& Umemura, Y. 2006. Effect of low-repetition jump training on bone mineral density in young women. Journal of Applied Physiology 100(3): 839-843.

Kromhout, D., Bloemberg, B., Seidell, J., Nissinen, A. \& Menotti, A. 2001. Physical activity and dietary fiber determine population body fat levels: The Seven Countries Study. International Journal of Obesity and Related Metabolic Disorders 25(3): 301-306.

MacKelvie, K.J., McKay, H.A., Petit, M.A., Moran, O. \& Khan, K.M. 2002. Bone mineral response to a 7-month randomized controlled, school-based jumping intervention in 121 prepubertal boys: Associations with ethnicity and body mass index. Journal of Bone and Mineral Research 17(5): 834-844.

Matthews, B.L., Bennell, K.L., McKay, H.A., Khan, K.M., Baxter-Jones, A.D.G., Mirwald, R.L. \& Wark, J.D. 2006. Dancing for bone health: A 3-year longitudinal study of bone mineral accrual across puberty in female non-elite dancers and controls. Osteoporosis International 17(7): 1043-1054.

Mohd Effendy, N., Mohamed, N., Muhammad, N., Mohamad, I.N. \& Shuid, A.N. 2012. The effects of Tualang honey on bone metabolism of postmenopausal women. EvidenceBased Complementary and Alternative Medicine 2012: Article ID. 938574.

Moniruzzaman, M., Khalil, M.I., Sulaiman, S.A. \& Gan, S.H. 2013. Physicochemical and antioxidant properties of
Malaysian honey produced by Apis cerana, Apis dorsata and Apis mellifera. BMC Complementary and Alternative Medicine 13(1): 43.

Morton, D.J., Barrett-Connor, E.L. \& Schneider, D.L. 2001. Vitamin C supplement use and bone mineral density in postmenopausal women. Journal of Bone and Mineral Research 16(1): 135-140.

Mosavat, M., Ooi, F.K. \& Mohamed, M. 2014. Effects of honey supplementation combined with different jumping exercise intensities on bone mass, serum bone metabolism markers and gonadotropins in female rats. BMC Complementary and Alternative Medicine 14(1): 126.

Njeh, C.F., Fuerst, T., Diessel, E. \& Genant, H.K. 2001. Is quantitative ultrasound dependent on bone structure? A reflection. Osteoporosis International 12(1): 1-15.

Nguyen, T.V., Center, J.R. \& Eisman, J.A. 2004. Bone mineral density-independent association of quantitative ultrasound measurements and fracture risk in women. Osteoporosis International 15(12): 942-947.

Ooi, F.K. \& Sahrir, N.A. 2018. Physical activity, bone remodelling and bone metabolism markers. Journal of Exercise, Sports \& Orthopedics 5(2): 1-4.

Ooi, F.K. \& Aziz, A. 2017. Bone metabolism markers in response to circuit training and honey supplementation in young males. Malaysian Journal of Medical Research 1(4): 28-34.

Ooi, F.K., Tavafzadeh, S.S., Hung, L., Hung, W. \& He, Y. 2014 Tibial bone mineral density, geometry, and mechanical properties in response to high-impact exercise and honey supplementation in rats. Asian Journal of Exercise \& Sports Science 11(2): 12-24.

Ooi, F.K., Singh, R. \& Singh, H.J. 2012. Changes in bone turnover markers and bone mass with reducing levels of jumping exercise regimens in female rats. Asian Journal of Sports Medicine 3(4): 225-232.

Ooi, F.K., Ismail, N. \& Abdullah, M.Y. 2011 Effects of combined aerobic dance exercise and honey supplementation on bone turnover markers in young females. Asian Journal of Exercise and Sports Science 8(1): 1-11.

Rahim, M., Ooi, F.K. \& Hamid, W.Z.W.A. 2016. Changes of bone metabolism markers and muscular performance with combined aerobic dance exercise and honey supplementation in adult women. Sports \& Exercise Medicine Open Journal 1(6): 186-197.

Remes, T., Väisänen, S.B., Mahonen, A., Huuskonen, J., Kröger, H., Jurvelin, J.S., Penttilä, I.M. \& Rauramaa, R. 2004. The association of bone metabolism with bone mineral density, serum sex hormone concentrations, and regular exercise in middle-aged men. Bone 35(2): 439-447.

Shafin, N., Othman, Z., Zakaria, R. \& Nik Hussain, N.H. 2014. Tualang honey supplementation reduces blood oxidative stress levels/activities in postmenopausal women. International Scholarly Research Notices 2014: Article ID. 364836

Tavafzadeh, S.S., Ooi, F.K., Chen, C.K., Sulaiman, S.A. \& Hung, L.K. 2015. Bone mechanical properties and mineral density in response to cessation of jumping exercise and honey supplementation in young female rats. BioMed Research International 2015: Article ID. 938782. 
Tavafzadeh, S.S., Ooi, F.K., Krasilshchikov, O. \& Sulaiman, S.A. 2011. Effect of a combination of jumping exercise and honey supplementation on the mass, strength and physical dimensions of bones in young female rats. Journal of ApiProduct and ApiMedical Science 3(1): 26-32.

Turner, C.H. \& Robling, A.G. 2003. Designing exercise regimens to increase bone strength. Exercise and Sport Sciences Reviews 31(1): 45-50.

Vetter, R.E. 2007. Effects of six warm-up protocols on sprint and jump performance. Journal of Strength and Conditioning Research 21(3): 819-823.

Wang, H., Kia, M. \& Dickin, D.C. 2019. Influences of load carriage and physical activity history on tibia bone strain. Journal of Sport and Health Science 8(5): 478-485.

Weeks, B.K. \& Beck, B.R. 2008. The BPAQ: A bone-specific physical activity assessment instrument. Osteoporosis International 19(11): 1567-1577.
Zaid, S.S.M., Sulaiman, S.A., Sirajudeen, K.N.M. \& Othman, N.H. 2010. The effects of Tualang honey on female reproductive organs, tibia bone and hormonal profile in ovariectomised rats-animal model for menopause. $B M C$ Complementary and Alternative Medicine 10(1): 82.

Exercise and Sports Science

School of Health Sciences, Health Campus

Universiti Sains Malaysia

16150 USM Kubang Kerian, Kelantan Darul Naim

Malaysia

*Corresponding author; email: nursyamsina@usm.my

Received: 9 September 2019

Accepted: 11 March 2020 